\title{
Intraoperative hemorrhage and increased spleen volume are risk factors for conversion to open surgery in patients undergoing elective robotic and laparoscopic splenectomy
}

Mehmet Aziret (ID), Bülent Koyun'(ID), Kerem Karaman'(ID), Cenk Sunu²(ID), Alper Karacan(ID), Volkan Öter ${ }^{1}($ ID), Fehmi Çelebi' (ID), Metin $\operatorname{Ercan}^{1}($ ID), Erdal Birol Bostanci'(ID)

\footnotetext{
${ }^{1}$ Clinic of General Surgery, Sakarya University Training and Research Hospital, Sakarya, Turkey

${ }^{2}$ Clinic of Hematology, Sakarya University Training and Research Hospital, Sakarya, Turkey

${ }^{3}$ Clinic of Radiology, Sakarya University Training and Research Hospital, Sakarya, Turkey

${ }^{4}$ Clinic of General Surgery, Health Science University Ankara City Hospital, Ankara, Turkey
}

\begin{abstract}
Objective: Minimal invasive surgery is one of the most popular treatment approaches which is safe and effective in experienced hands in different clinical practices. In the present study, we aimed to evaluate the risks factors for conversion to open splenectomy and the performance of indirect hilum dissection technique.

Material and Methods: A total of 56 patients who underwent laparoscopic or robotic splenectomy for isolated spleen diseases were included into the study. Patients were divided into two groups as robotic or laparoscopic splenectomy (Group 1; $n=48$ ) and conversion to open surgery (Group 2; $\mathrm{n}=8$ ). Patients were retrospectively evaluated according to clinical, biochemical, hematological and microbiological parameters and morbidity.

Results: No statistically significant difference was found between the groups in terms of age, gender, body mass index (BMI), ASA score, co-morbid disease, operation time, hospital stay, follow-up period, accessory spleen, diagnosis, international normalized ratio (INR), red cell distribution width (RDW), platelet distribution width (PDW), platelet to lymphocyte ratio (PLR), neutrophil to lymphocyte ratio (NLR), reapplication, splenosis, surgical site infection, vascular thrombus and incisional hernia $(p>0.05)$. On the other hand, intraoperative splenic hilum hemorrhage and increased spleen size $(p<0.05)$ were higher in the conversion to open surgery group. In logistic regression analysis, intraoperative splenic hilum hemorrhage $(B=4.127)(O R=61.974)(95 \% \mathrm{Cl}=3.913-$ 981.454) $(p=0.003)$ and increased spleen volume $(B=3.114)(O R=22.509)(95 \% C l=1.818-278.714)(p=0.015)$ were found as risk factors for conversion to open surgery.
\end{abstract}

Conclusion: Intraoperative hemorrhage from the splenic hilum and increased spleen volume $\left(>400 \mathrm{~cm}^{3}\right)$ are risk factors for conversion to open splenectomy in patients undergoing elective robotic or laparoscopic splenectomy. Indirect splenic hilum dissection can decrease intraoperative hemorrhage and conversion to open surgery.

Keywords: Conversion to open surgery, indirect hilum dissection, laparoscopic splenectomy, robotic splenectomy

Cite this article as: Aziret $M$, Koyun $B$, Karaman $K$, Sunu C, Karacan A, Öter V, et al. Intraoperative hemorrhage and increased spleen volume are risk factors for conversion to open surgery in patients undergoing elective robotic and laparoscopic splenectomy. Turk J Surg 2020; 36 (1): 72-81.

Corresponding Author

Mehmet Aziret

E-mail:mhmtaziret@gmail.com

Received: 14.05.2019

Accepted: 25.11.2019

Available Online Date: 18.03.2020

(๑) Copyright 2020 by Turkish Surgical Society Available online at www.turkjsurg.com

DOI: $10.5578 /$ turkjsurg.4535

\section{INTRODUCTION}

Minimal invasive surgery (MIS) is feasible and safe with growing popularity in different clinical practices (1-5). Laparoscopic and robotic splenectomies are subgroups of MIS and have been increased due to good exposure of the surgical field, less bleeding, postoperative abdominal pain and shorter length of the hospital stay (68). Robotic or laparoscopic splenectomies (RLS) are performed usually for benign blood disorders, splenic cystic disease, and play a crucial role in the management of a many malignant lymphoproliferative disorders $(9,10)$.

RLS, which is associated with good exposure, less bleeding, postoperative abdominal pain, shorter length of hospital stay and better cosmetic results, require expertise such as insertion of trocars and ports, proper dissection of hilar vessels, removing of the spleen due to uncontrolled intraoperative hemorrhage and conversion to open splenectomy (11-14). Many published studies have assessed the safety and practicability of RLS (12-17). Nevertheless, a few trials are reported regarding the risks factors of conversion to open splenectomy for RLS in the literature (18). In the present study, we aimed to evaluate the risk factors of conversion to open splenectomy for isolated splenic diseases in patients who underwent RLS. 


\section{MATERIAL and METHODS}

\section{Patients and Ethics}

This study was conducted in the general surgery department between September 2013 and August 2018. A total of 56 patients who underwent laparoscopic or robotic splenectomy for isolated spleen diseases including benign blood disorders, cystic and malignant diseases were included into the study. Patients were retrospectively evaluated in terms of age, gender, body mass index (BMI), co-morbidity, diagnosis, ASA score, splenomegaly or spleen volume, biochemical, hematological and microbiological parameters, morbidity and mortality. The Ethical Committee of the Sakarya University Education and Research Hospital approved the study protocol (71522473/050.01.04/2).

\section{Study Design}

Of the splenectomized 255 patients, 56 RLS cases were enrolled in the study. The patients were divided into two groups;

- Group 1: Patients with laparoscopic and robotic splenectomy $(n=48)$,

- Group 2: Patients with conversion from RLS to open splenectomy $(n=8)$.

The flow-chart of the study is illustrated in Figure 1. Blood samples were taken from all patients before laparoscopic or robotic splenectomy. Indication of RLS was considered after hematology and anesthesiology consultation.

\section{Inclusion Criteria}

- Patients who were resistant to medical treatment for isolated benign or malignant splenic diseases.

- Hematological disorders including idiopathic thrombocytopenic purpura (ITP) and hereditary spherocytosis, splenic cyst or splenic malignity.

- Patients with a platelet count higher than 50.000/IL.

- Patients with normal hemostatic parameters (PTZ/INR, aPTZ, etc.).

\section{Exclusion Criteria}

- Patients who could not be followed up

- Patients with abnormal coagulation tests, immunosuppression, sepsis

- Patients without isolated splenic disease

\section{Vaccinations and Antibiotic Prophylaxis}

Hemophilus influenza, meningococcal, and pneumococcal vaccinations were administered to all patients following the evaluation of the infectious disease clinic. Most of the patients (2/3 cases) were vaccinated after postoperative $14^{\text {th }}$ day. Others were vaccinated at least two weeks before the surgery. An antibiotic prophylaxis was performed with intravenous $1 \mathrm{~g}$ cefazolin before anesthesia induction.

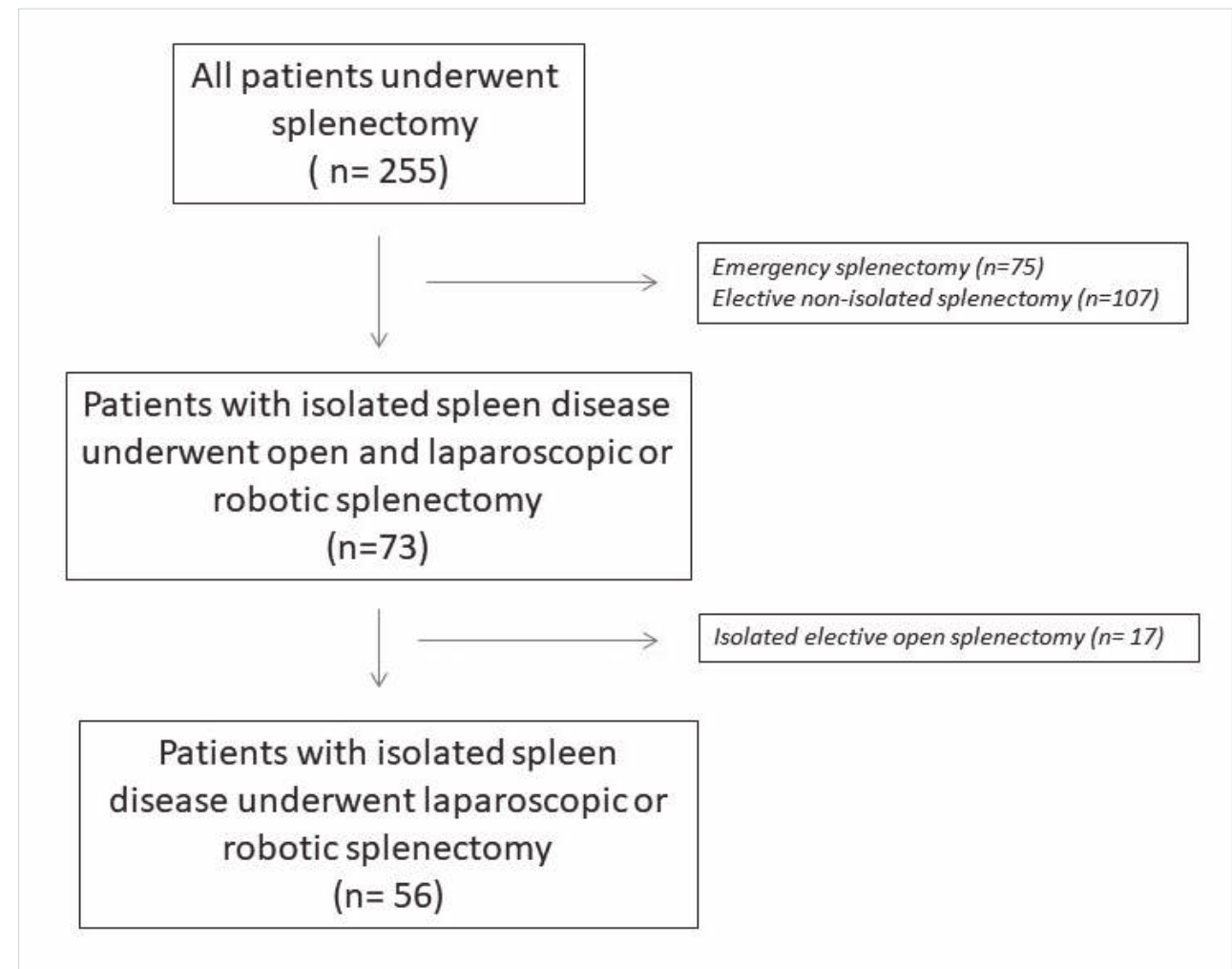

Figure 1. Flowchart of the study. 


\section{Indications for Splenectomy}

ITP is the most common hematologic disorder for splenectomy. Splenectomy is usually performed only in cases in which corticosteroid therapy fails to achieve remission. A very important part of the operative procedure is the detection of accessory spleens. Accessory spleens or accidentally re-implanted splenic tissue may cause recurrent thrombocytopenia after splenectomy. Splenectomy is indicated when conservative treatment is ineffective in patients with hereditary spherocytosis (9).

Hodgkin's disease (lympho-granulomatosis) and non-Hodgkin's lymphomas are grouped together under the heading "malignant lymphomas". They develop primarily in lymphatic tissue, mostly in lymph nodes, and less than $1 \%$ occurs in the spleen (10). Splenectomy is performed for diagnosis and staging of the disease.

\section{Perioperative Platelet Account, Identification of Accessory Spleen and Calculation of the Splenic Volume}

Abdominal ultrasound (US) and computerized tomography (CT) scans were used preoperatively in all patients. Splenectomy was performed in patients with a platelet count higher than 50.000/L. Fresh frozen plasma or platelet apheresis was given to increase the platelet count, if the platelet counts were less than 50.000/IL. All patients were screened with CT for accessory spleen. The accessory spleen was removed when it was detected during operation. Contrast-enhanced CT images of each spleen were obtained by scanning in the axial plane and were reformatted in sagittal-transverse planes. Splenic length, width, and thickness measurements were obtained. Length was measured along the long axis, from the dome to the tip of the spleen, in the sagittal plane. Width was the longest (straight) organ diameter in the transverse plane. Thickness was the distance between the center (inner) and pe- ripheral (outer) surface, measured at the level of the splenic hilum on the transverse plane. This was identified on the section with the largest width. Splenic length, width, and thickness measurements were obtained by positioning electronic calipers manually on the image. To assess interobserver and intraobserver variability, three separate measurements of each distance (i.e., length, width, and thickness) were recorded by two separate independent observers, then an average for each observer was determined. Splenic volume was calculated using the standard clinical ellipsoid equation of length $\mathrm{x}$ width $\mathrm{x}$ thickness $\mathrm{x} 0.523$ (normal volume range 107 to $314.5 \mathrm{~cm}^{3}$ ) (11).

\section{Operative Technique}

Robotic splenectomy: The patients were positioned in a right modified lateral decubitus position under general anesthesia. A $\mathrm{CO} 2$ pneumoperitoneum of $12 \mathrm{mmHg}$ was established using a Veress needle introduced through a between umbilicus and inferior arcus costarium positioned on the patient's left side. Four or five ports (three 8-mm robotic arms, 12-mm camera and 11$\mathrm{mm}$ assistant) were inserted under direct vision, and localization of ports was similar to the placements in laparoscopic splenectomy. At first, docking of the robotic arms were performed, and then the dissection was performed with bipolar cautery scissors in the right hand and the Maryland forceps in the left hand. A $3^{\text {rd }}$ arm of the robot was used for retraction of the spleen and other tissues. In some cases, an assistant port was inserted in case of hemoclip application when necessary. The peritoneal attachments, splenic ligaments and adjacent tissues were dissected with monopolary electro-cautery and bipolary electro-cautery. The splenic hilar vessels were dissected and ligated with hemo-lock clips. After hilum dissection, the operation underwent similar to the laparoscopic splenectomy (Figure 2).

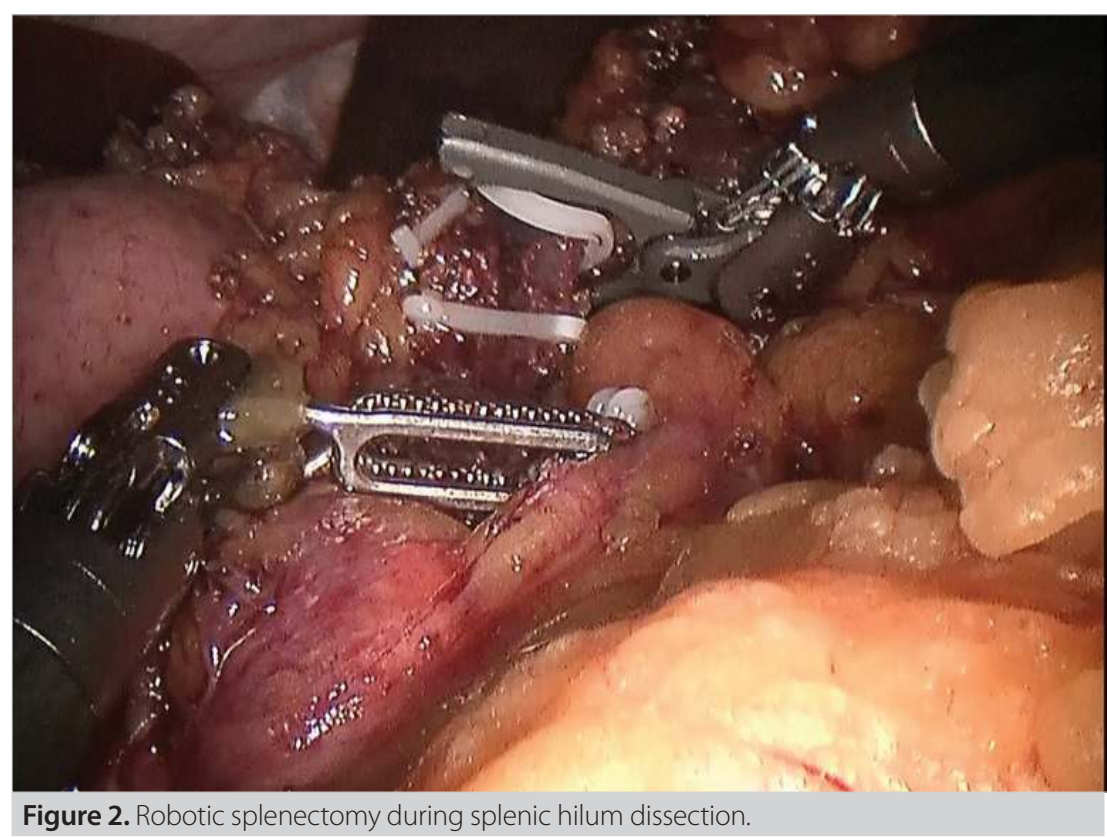


Laparoscopic splenectomy: All patients were positioned in a right and lateral decubitus following general anesthesia. Prior to making the trocars insertion, a Foley catheter was inserted into the bladder. A three or four-port technique was used on all patients and different surgeons performed the laparoscopic or robotic splenectomies. A 10-mm port was inserted under the arcus costarium in midclavicular line using the Veres needle. Pneumoperitoneum was applied with carbon dioxide $\left(\mathrm{CO}_{2}\right)$, and intraabdominal pressure was fixed at $12 \mathrm{mmHg}$. Next, a $5-\mathrm{mm}$ trocar was inserted into the epigastric area just inferior to the xiphoid process. A 10-mm trocar was inserted to the left upper quadrant under the direct $30^{\circ}$ scope vision (Figure 3 ). The possibility of hemorrhaging or organ injury occurring in connection with trocar was controlled prior to performing the splenectomy. After the spleen was visible, it was controlled from the other adjacent organs or tissues. A 5-mm bipolar vessel sealer was used for the ligament of spleen dissection (splenocolic, splenophrenic and splenogastric). Once the base of the ligament of spleen dissection was performed, splenic hilum was revealed. The splenic vein and splenic artery were ligated using vascular clips under direct vision. In a few patients, these vascular tissues were sealed with 10-mm (Figure 4). Splenectomy specimen was placed in large retrieval bag. The spleen was extracted through the left upper quadrant port following smashing the spleen in the retrieval bag. After removing the spleen, the splenectomy area was washed with serum physiologic (0.9\% sodium-chlo-

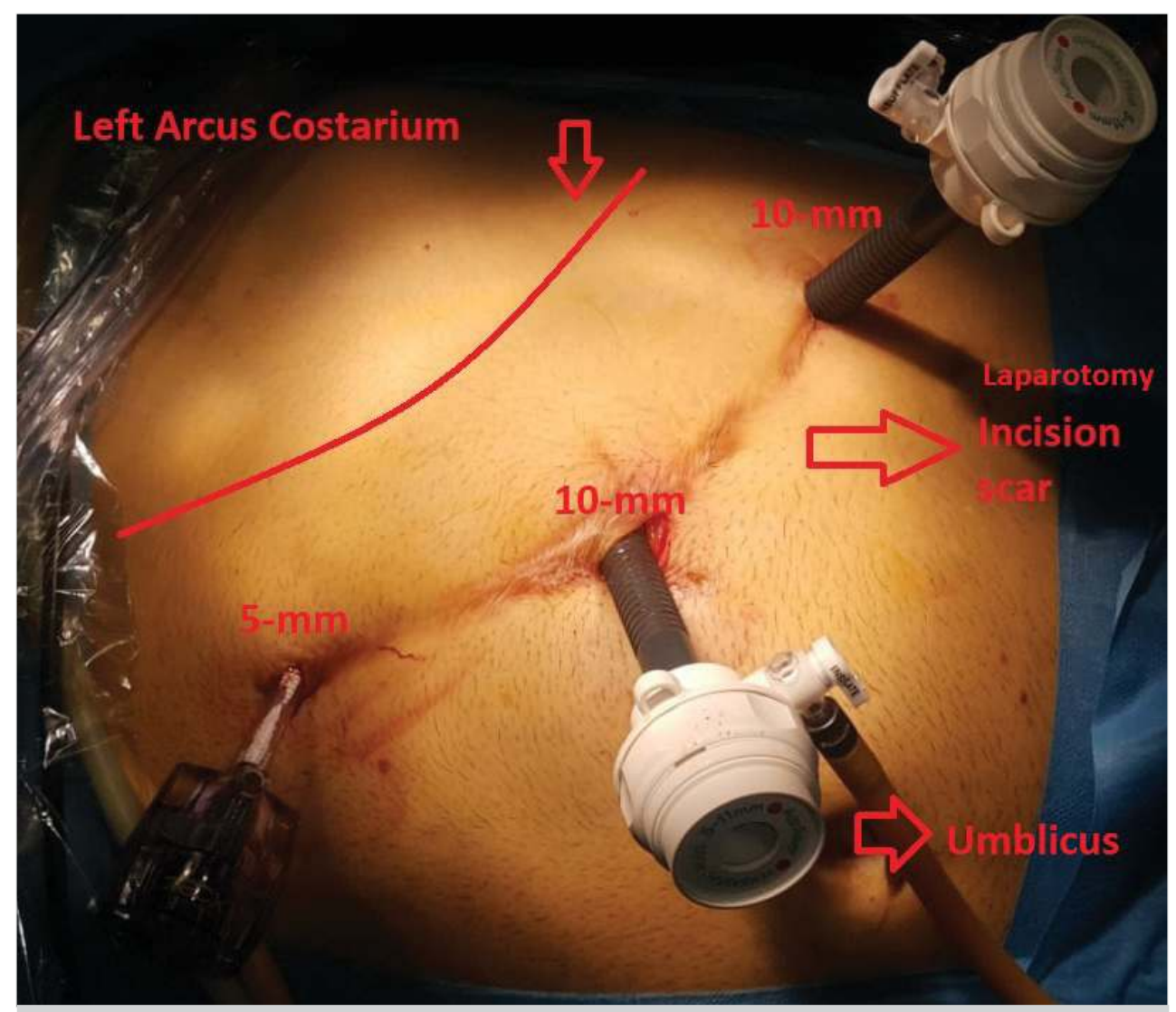

Figure 3. Port placements for laparoscopic splenectomy.

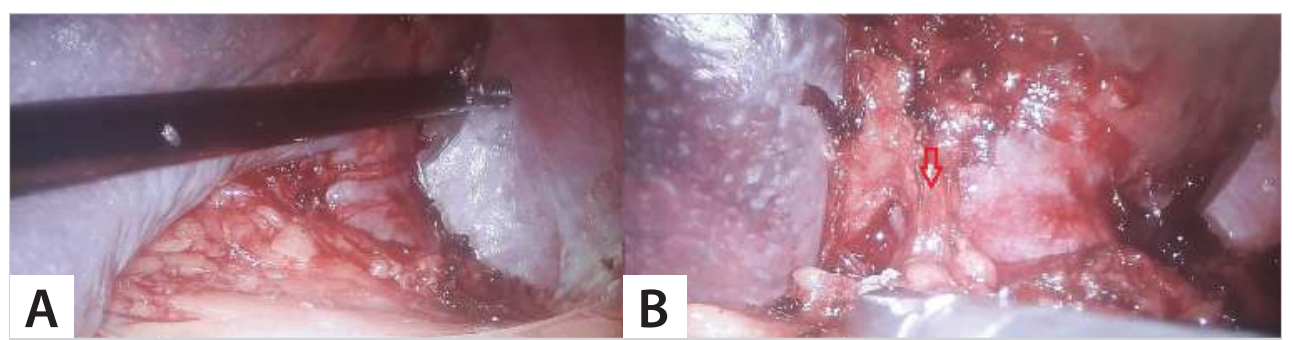

Figure 4. Indirect splenic hilum dissection; removing of the spleno-colonic and spleno-diapragmatic ligaments (A), and splenic vascular plane after bilateral hilum dissection (arrow: splenic pedicle) (B). 
ride) and then aspirated. A drain was used in all patients for the purpose of controlling hemostasis. A mini-laparotomy $(<6 \mathrm{~cm})$ was performed in the absence of large retrieval bag in left subcostal area.

\section{Postoperative Care, Anticoagulation and Follow-up}

In all patients, an intensive monitoring was provided at the early postoperative hours in terms of pulse, blood pressure, temperature and drains. After eight hours, hemoglobin, platelet count and INR were checked. Oral feeding and mobilization were started at the postoperative 8th hour. Drain was removed provided the drainage was less than $30 \mathrm{~mL}$ over $48 \mathrm{~h}$. Most of the patients were discharged with low-molecular weight heparin (LMWH) of $0.4 \mathrm{IU} / \mathrm{mL}$ during the first 2 weeks of the postoperative period. The patients were followed up to ensure well healing of wounds and hemodynamic parameters in the first 1 month. After this period, patients who had hematological disease were followed up by hematology.

\section{Statistical Analysis}

Data analysis was performed by using IBM SPSS Statistics version 21.0 software (IBM Corporation, Armonk, NY, USA). Whether the distributions of continuous variables were normal or not was determined by Shapiro-Wilk test. Continuous variables were shown as median $\left(25^{\text {th }}-75^{\text {th }}\right)$ percentiles. Number of cases and (\%) were used for categorical data. While mean differences between the groups were compared by Student's t test, Mann-Whitney $U$ test was used for comparisons of the not normally distributed data. Categorical variables were analyzed by Continuity Corrected Chi-square or Fisher's exact test, where appropriate. The optimal cut-off points for spleen volume to assess conversion to open splenectomy were evaluated by receiver operating characteristics (ROC) analyses, calculating the area under the curve to give the maximum sum of sensitivity and specificity. Determining the best predictor(s) which affected both conversions to open surgery was evaluated by Multiple Logistic Regression Analyses. Any variable whose univariable test had a $p$ value $<0.25$ was accepted as a candidate for the multivariable model along with all variables of known clinical importance. Odds ratios, 95\% confidence intervals and Wald statistics for each independent variable were also calculated. A p value less than 0.05 was considered statistically significant.

\section{RESULTS}

\section{Perioperative Outcomes}

Of the 255 patients, 56 cases were enrolled in the study, whereas 199 patients were excluded due to failing of the inclusion criteria. Fifty-one patients underwent laparoscopic and 5 patients underwent robotic splenectomy.

Mean age was $42.3( \pm 15.5)$ years. Thirty-four (62.5\%) patients were females and 21 (37.5\%) patients were males. Mean BMI was 26.1 $( \pm 5.5) \mathrm{kg} / \mathrm{m}^{2}$. Median ASA score was 2 (min-max; 1-3). Median follow-up time was 25.2 (1-89) months. Most of the patients (39 patients, 69.6\%) had steroid usage, and comorbidities were hypertension (14.2\%), diabetes mellitus (14.2\%), coronary artery disease or congestive heart failure (3.5\%), chronic obstructive lung disease (3.5\%) and others (cerebrovascular disease, depression, lymphoma) (5.3\%), respectively. Median operation time of laparoscopic and robotic splenectomy was 172.5 (52-450) minutes. A statistical difference was not found in terms of age, gender, BMI, ASA, co-morbidity, operation time, follow up, length of the hospital stays and accessory spleen in two groups ( $p>0.05$ ) (Table 1).

Median spleen volume was $285(129-950) \mathrm{cm}^{3}$, and the conversion to open splenectomy group had significantly higher spleen volume than the laparoscopic and robotic splenectomy group ( $p=0.01$ ) (Table 1). Indications for splenectomy were ITP (67.8\%), followed by splenic cyst (14.3\%), Iymphoma (7.1\%), hereditary spherocytosis (5.3\%) and splenic artery aneurysm or splenic infarct (5.3\%), respectively. There was no difference in terms of diagnosis between the two groups ( $p>0.05$ ) (Table 2).

Median INR value was 0.95 (min-max; 0.75-1.38); platelet distribution width (PDW) was 17.9\% (min-max; 16.0-24.8); red cell distribution width (RDW) was $16.7 \%$ (min-max; 14.4-29.7), platelet to lymphocyte ratio (PLR) was 106.8 (min-max; 13.6-510) and neutrophil to lymphocyte ratio (NLR) was 3.3 (min-max; 0.537.5), respectively (Table 3 ).

No statistically difference was found in terms of PDW, RDW, PLR, NLR, preoperative adhesion, robotic surgery and mini-laparotomy in two groups ( $p>0.05$ ) (Table 3). In our study, there were a total of 5 patients who underwent robotic splenectomy, and none of these patients had conversion to open splenectomy. There was no statistically significant difference in terms of the robotic surgery between the two groups. This result can be due to the increased concentration in the learning curve of robotic surgery and advanced surgeon's experience in laparoscopic surgery ( $p>0.05)$. Sixteen (28.5\%) patients underwent mini-laparotomy for removing of the spleen in the absence of large retrieval bag (Table 1 and 3).

\section{Complications}

Mortality did not occur during the first postoperative month. Most of the complications were minor complications including incisional hernia [5 (8.9\%) patients], wound infection [3 (5.3\%) patients], splenosis [1 (1.7\%) patient], and readmission to hospital [8 (14.2\%) patients]. Patients with readmission were hospitalized, and wound care was applied on 3 of them, another three underwent incisional hernia repair and 2 of patients received anticoagulant treatment for branch of the portal vein thrombosis (PBVT). Patients with PBVT were followed up in the outpatient clinic with $L M W H$ followed by oral Warfarin. A non-abundant hemorrhage occurred in $9(16 \%)$ patients. These patients were followed up and treated medically and carefully including erythrocyte suspension, fresh frozen plasma and vitamin $\mathrm{K}$ supple- 


\begin{tabular}{|c|c|c|c|c|}
\hline & $\begin{array}{c}\text { Total } \\
(n=56)\end{array}$ & $\begin{array}{l}\text { Laparoscopic and robotic splenectomy } \\
\qquad(n=48)\end{array}$ & $\begin{array}{l}\text { Conversion to open splenectomy } \\
\qquad(n=8)\end{array}$ & $p$ \\
\hline Age & $42.3 \pm 15.5$ & $41.3 \pm 14.5$ & $48.1 \pm 21.3$ & $0.260^{\dagger}$ \\
\hline $\begin{array}{l}\text { Gender } \\
\text { Male } \\
\text { Female }\end{array}$ & $\begin{array}{l}21(37.5 \%) \\
35(62.5 \%)\end{array}$ & $\begin{array}{l}16(33.3 \%) \\
32(66.6 \%)\end{array}$ & $\begin{array}{l}5(62.5 \%) \\
3(37.5 \%)\end{array}$ & $0.235^{\$}$ \\
\hline $\mathrm{BMI}\left(\mathrm{kg} / \mathrm{m}^{2}\right)$ & $26.6 \pm 4.1$ & $26.7 \pm 4.4$ & $25.8 \pm 2.6$ & $0.573^{\dagger}$ \\
\hline ASA & & & & 0.599 \\
\hline $\begin{array}{l}\text { I } \\
\text { II } \\
\text { III }\end{array}$ & $\begin{array}{c}5(8.9 \%) \\
41(73.2 \%) \\
6(10.7 \%) \\
\end{array}$ & $\begin{array}{c}4(8.3 \%) \\
37(77 \%) \\
4(8.3 \%)\end{array}$ & $\begin{array}{l}1(12.5 \%) \\
4(50 \%) \\
2(25 \%)\end{array}$ & \\
\hline Steroid usage & $39(69.6 \%)$ & 35 (72.9\%) & $4(50 \%)$ & $0.228^{\$}$ \\
\hline \multicolumn{5}{|l|}{ Co-morbidity } \\
\hline $\begin{array}{l}\text { HT } \\
\text { DM } \\
\text { CAD/CHF } \\
\text { COLF } \\
\text { Others } \\
\text { CVD, Depression, lymphoma }\end{array}$ & $\begin{array}{l}8(14.2 \%) \\
8(14.2 \%) \\
2(3.5 \%) \\
2(3.5 \%) \\
3(5.3 \%)\end{array}$ & $\begin{array}{l}6(12.5 \%) \\
6(12.5 \%) \\
2(4.1 \%) \\
2(4.1 \%) \\
3(6.2 \%)\end{array}$ & $\begin{array}{c}2(25 \%) \\
2(25 \%) \\
- \\
- \\
-\end{array}$ & $\begin{array}{c}0.320^{\$} \\
0.320^{\$} \\
>0.999^{\$} \\
>0.999^{\$} \\
>0.999^{\$}\end{array}$ \\
\hline Operation time & $172.5(52-450)$ & $163(52-450)$ & $199(90-349)$ & $0.233^{\pi}$ \\
\hline Length of hospital stay & $5(3-21)$ & $5(3-21)$ & $7(4-9)$ & $0.378^{\pi}$ \\
\hline Robotic splenectomy & $5(8.9 \%)$ & $5(10.4 \%)$ & - & $>0.999^{\$}$ \\
\hline Laparoscopic splenectomy & $51(71.5 \%)$ & $43(84.6 \%)$ & $8(15.6 \%)$ & $0.159^{\$}$ \\
\hline Follow up & $25.2(1-89)$ & $22.6(1-66)$ & $22.8(1-72)$ & $>0.999^{\natural}$ \\
\hline Spleen volume & 285 (129-950) & $270(129-950)$ & $521(212-695)$ & $0.01^{\pi}$ \\
\hline $\begin{array}{l}\text { Accessory spleen } \\
\text { No } \\
\text { Yes }\end{array}$ & $\begin{array}{c}37(66 \%) \\
13(23.2 \%)\end{array}$ & $\begin{array}{c}31(64.5 \%) \\
13(27 \%)\end{array}$ & $\begin{array}{c}6(75 \%) \\
-\end{array}$ & $0.319^{\$}$ \\
\hline
\end{tabular}

Table 2. Comparison of groups in terms of diagnosis

\begin{tabular}{|c|c|c|c|c|}
\hline & $\begin{array}{c}\text { Total } \\
(n=56)\end{array}$ & $\begin{array}{l}\text { Laparoscopic and robotic splenectomy } \\
\qquad(n=48)\end{array}$ & $\begin{array}{l}\text { Conversion to open surgery } \\
\qquad(n=8)\end{array}$ & p value $^{\dagger}$ \\
\hline ITP & $38(67.8 \%)$ & $33(68.7 \%)$ & $5(62.5 \%)$ & 0.703 \\
\hline Hereditary spherocytosis & $3(5.3 \%)$ & $2(4.1 \%)$ & $1(12.5 \%)$ & 0.376 \\
\hline Splenic cyst & $8(14.2 \%)$ & $7(14.5 \%)$ & $1(12.5 \%)$ & $>0.999$ \\
\hline Splenic artery aneurysm or infarct & $3(5.3 \%)$ & $2(4.1 \%)$ & $1(12.5 \%)$ & 0.376 \\
\hline Malignancy & $4(7.1 \%)$ & $4(8.3 \%)$ & - & $>0.999$ \\
\hline
\end{tabular}

mentation. Major hemorrhage occurred during operation in 7 (12.5\%) patients. Of the 16 patients (with perioperative bleeding patients), seven cases were converted to open splenectomy. An improved splenosis patient was followed up as outpatient with normal range platelet level. There was no difference in terms of readmission, splenosis, surgical side infection, incisional hernia and PBVT $(p>0.05)$. The rates of intraoperative hemorrhage were higher in conversion to open surgery group ( $p<0.001$ ) (Table 3 ). Moreover, the conversions to open surgery were associated with expertise of the surgical team because the number of conversions were 5 (8.9\%) patients and $3(5.3 \%)$ patients in the first half of study and second half of study, respectively. 
Table 3. Alterations of biochemical parameters and complications in groups

\begin{tabular}{|c|c|c|c|c|}
\hline & $\begin{array}{c}\text { Total } \\
(n=56)\end{array}$ & $\begin{array}{l}\text { Laparoscopic and robotic splenectomy } \\
\qquad(\mathrm{n}=48)\end{array}$ & $\begin{array}{l}\text { Conversion to open surgery } \\
\qquad(\mathrm{n}=8)\end{array}$ & $p$ value \\
\hline INR & $0.95(0.75-1.38)$ & $0.95(0.80-1.38)$ & $0.97(0.75-1.1)$ & $0.765^{\dagger}$ \\
\hline PDW & $17.9(16.0-24.8)$ & $17.8(16.0-24.8)$ & $18.4(17.2-21.7)$ & $0.550^{\dagger}$ \\
\hline RDW & $16.7(14.4-29.7)$ & $16.6(14.7-29.7)$ & $18.1(15.4-20.8)$ & $0.197^{\dagger}$ \\
\hline PLR & $106.8(13.6-510.0)$ & $100.7(13-510)$ & $130.5(47-180)$ & $0.404^{\dagger}$ \\
\hline NLR & $3.3(0.5-37.5)$ & $3.3(0.4-37.5)$ & $2.5(0.8-6.9)$ & $0.242^{+}$ \\
\hline Adhesion & $6(10.8 \%)$ & $4(8.3 \%)$ & $2(25 \%)$ & $0.200^{\ddagger}$ \\
\hline Increased spleen volume $\left(>400 \mathrm{~cm}^{3}\right)$ & $16(20.8 \%)$ & $10(17.9 \%)$ & $6(75 \%)$ & $0.005^{\ddagger}$ \\
\hline Mini-laparotomy & $16(28.5 \%)$ & $16(33.3 \%)$ & - & $0.089^{\ddagger}$ \\
\hline Readmission & $8(14.2 \%)$ & $6(12.5 \%)$ & $2(25 \%)$ & $0.329^{\ddagger}$ \\
\hline \multicolumn{5}{|l|}{ Total complications } \\
\hline Hemorrhage & $16(28.5 \%)$ & $9(18.7 \%)$ & $7(87.5 \%)$ & $<0.001^{\ddagger}$ \\
\hline Incisional hernia & $5(8.9 \%)$ & $3(6.2 \%)$ & $2(25 \%)$ & $0.104^{\ddagger}$ \\
\hline Surgical side infection & $3(5.3 \%)$ & $2(4.1 \%)$ & $1(12.5 \%)$ & $0.330^{\ddagger}$ \\
\hline PMVT & $2(3.5)$ & $2(4.1 \%)$ & - & $>0.999$ \\
\hline Splenosis & $1(1.7 \%)$ & $1(2 \%)$ & - & $>0.999$ \\
\hline
\end{tabular}

Table 4. Risk factors of conversion to open surgery

\begin{tabular}{|c|c|c|c|c|c|c|c|c|}
\hline & & & & & & \multicolumn{3}{|c|}{$95 \% \mathrm{Cl}$ for $\operatorname{EXP}(\mathrm{B})$} \\
\hline & B & S.E. & Wald & df & $\operatorname{Exp}(B)$ & Lower & Upper & $p$ value \\
\hline Intraoperative Hemorrhage & 4.127 & 1.409 & 8.574 & 1 & 61.974 & 3.913 & 981.454 & 0.003 \\
\hline Spleen volume $\left(>400 \mathrm{~cm}^{3}\right)$ & 3.114 & 1.284 & 1.284 & 1 & 22.509 & 1.818 & 278.714 & 0.015 \\
\hline Constant & 5.465 & 1.516 & 12.992 & 1 & .004 & & & $<0.001$ \\
\hline
\end{tabular}

\section{Risk Factors for Development of Complications}

No significant difference was found between the patients converted to open splenectomy and those who had not according to age, gender, BMI, ASA, co-morbidity, operation time, follow up, length of the hospital stay and accessory spleen ( $p>0.05$ ).

Patients with conversion to open splenectomy had significantly higher splenic volume and splenic hilum hemorrhage than laparoscopic or robotic splenectomy group $(p=0.01$ and $p<0.001$; respectively).

ROC analysis for spleen volume to assess conversion to open splenectomy measurements revealed that the under-curve area was significant in distinguishing patients. The cut-off value for spleen volume to determine conversion to open surgery was $416 \mathrm{~cm}^{3}$ with $87.5 \%$ sensitivity and $80 \%$ specificity. In univariate analysis, all variables identified as $p<0.25$ were included as risk factors for multiple logistic regression model. Intraoperative hemorrhage and spleen volume $\left(>400 \mathrm{~cm}^{3}\right)$ were found as risk factors for conversion to open surgery. The rates of conversion to open splenectomy were correlated with increased intraoperative splenic hilum hemorrhage in patients undergoing laparoscopic and robotic splenectomy. When intraoperative hilum hemorrhage occurred, it was significantly associated with increased rate of conversion to open surgery with a risk of 61 times $(B=4.127)(O R=61.974)(95 \% C l=3.913-981.454)(p=$ 0.003). Moreover, a significant association was found between the rates of conversion to open splenectomy and increased spleen volume $(B=3.114)(O R=22.509)(95 \% C l=1.818-278.714)$ $(p=0.015)$ (Table 4).

\section{DISCUSSION}

This is the first study which assesses spleen volume for predicting the risk of conversion to open surgery. We found that a spleen volume higher than $400 \mathrm{~cm}^{3}$ increases the risk of conversion to open surgery 22.5 times. Secondly, intraoperative hemorrhage from the splenic hilum has a 61 -fold risk of conversion 
to open surgery ( $p=0.015$ and $p=0.003$, respectively). On the other hand, it was found that age, gender, BMI, ASA, co-morbidity, operation time, accessory spleen, INR, PDW, RDW, PLR, NLR, preoperative adhesion, and robotic surgery were not associated with conversion to open surgery ( $p>0.05)$.

Minimal invasive surgery, whether robotic or laparoscopic, has become popular due to less postoperative abdominal pain, shortened length of hospital stay, and early return to normal daily activity (1-8). Robotic surgery surpasses laparoscopic technique by providing more articulation and maneuverability $(7,8)$. RLS is frequently used for hematological disorders of the spleen such as ITP, hereditary spherocytosis, lymphoma and splenic cyst (9-11).

There are some risk factors for conversion to open surgery including intraoperative hemorrhage, massive splenomegaly (over $1 \mathrm{~kg}$ ), a low platelet count, obesity, and adhesions. In the literature, conversion to open rates ranges from $0.7 \%$ to $30 \%$ $(6,12-17)$. In the present study, conversion to open surgery rate was $14.2 \%$, which is comparable with the literature $(1,3,6,12-17)$. Here, it is known as 'difficult splenic hilum', occurrence of abundant bleeding due to hardly of dissection and lead to slippage of knots or clips in splenic hilum (18). In patient with difficult splenic hilum, there is lymphatic edema, lymphadenopathy, chronic infection or fibrotic bands at the splenic hilum increase the conversion rate. Vecchio et al. (18) suggest ligation of hilar vessels and branches by using intracorporeal sutures. Two approaches can be recommended for hilum dissection as the following: direct hilum dissection and indirect hilum dissection techniques. In the direct dissection technique; the splenic artery and vein are ligated before the dissection of the splenic hilum. However, massive hemorrhage may sometimes occur during the ligation of these vessels. On the other hand, the dissection starts in the indirect hilum dissection technique from the posterolateral region by dissection of the splenocolonic, splenophrenic and gastrosplenic ligaments towards the splenic hilum. Furthermore, if possible, we recommend a $360^{\circ}$ circumferentially dissection for exactly revealing the splenic artery and vein, so surgeon can behave safely and easily before splenic hilum ligation (Figure 4a, 4b). Patients with malignancy, lymphoma, liver cirrhosis and chronic infections disease have always a difficult splenic hilum to dissection so a careful and sharp dissection should be performed to decrease the hemorrhage rate.

In these patients, Giza et al. (19) recommend robotic splenectomy over laparoscopic due to the ability of better articulation. Further, they have suggested sponges-assisted spleen retraction to avoid laceration during the indirect splenic hilum dissection technique. Splenic hilum dissection can be performed closely to the spleen to prevent injury of the pancreatic tail.

Another indication for conversion to open surgery is the enlarged spleen volume or splenomegaly because splenomegaly cannot allow adequate surgical exposure, suitable location of ports and maneuverability during the laparoscopic and robotic splenectomy which raises the risk of hemorrhage (20-23). On the other hand, despite longer operative time of laparoscopic splenectomy, Pattenden et al., Owera et al. and Silecchia et al. suggest laparoscopic splenectomy in patients with splenomegaly after an effective learning curve $(15,24,25)$. Currently, with the advanced minimally invasive method, robotic splenectomy has been used for first training of robotic systems and routine clinical practice. Cavaliere et al. suggest robotic splenectomy due to less intraoperative bleeding for splenomegaly (26). On the other hand, Bodner et al. and Gelmini et al. have reported that robotic surgery is not cost-effective and the operation time is longer than in LS $(27,28)$. We recommend indirect hilum dissection approach which can allow easy and safe vascular clipping. Thus, risk of intraoperative hemorrhage and conversion to open surgery is reduced with this technique.

The present study has some limitations. First, it is retrospective. Secondly, the sample size is small. On the other hand, this is the first study which measured the splenic volume to determine the risk of conversion to open surgery.

\section{CONCLUSION}

Intraoperative hemorrhage from the splenic hilum and a spleen volume $>400 \mathrm{~cm}^{3}$ are risk factors for conversion to open splenectomy in patients undergoing minimal invasive surgery. Indirect splenic hilum dissection technique seems to be feasible in reducing bleeding from the splenic hilum.

Ethics Committee Approval: The Ethical Committee of the Sakarya University Education and Research Hospital approved the study protocol (71522473/050.01.04/2).

Informed Consent: Not required in this study.

Peer-review: Externally peer-reviewed.

Author Contributions: Concept - M.A., K.K.; Design - M.E.; Supervision - F.Ç.; Data Collection and/or Processing - C.S., A.K.; Analysis and Interpretation M.A., B.K.; Literature Search - V.Ö.; Writing Manuscript - M.A., E.B.B.; Critical Reviews - E.B.B

Conflict of Interest: The authors have no conflicts of interest to declare.

Financial Disclosure: The authors declared that this study has received no financial support.

\section{REFERENCES}

1. Habermalz B, Sauerland S, Decker G, Delaitre B, Gigot JF, Leandros E. Laparoscopic splenectomy: the clinical practice guidelines of the European Association for Endoscopic Surgery (EAES). Surg Endosc 2008;22:821-48. [CrossRef]

2. Aziret M, Ercan M, Toka B, Parlak E, Karaman K. Risk factors for morbidity in walled-off pancreatic necrosis and performance of continuous postoperative lavage: a single-center experience. Ulus Travma Acil Cerrahi Derg 2018;24:488-96. [CrossRef] 
3. Vecchio R, Gelardi V, Intagliata E, Barbaros U, Cacciola RR, Cacciola E. How to prevent intraoperative risks and complications in laparoscopic splenectomy. G Chir 2010;31:55-61. [CrossRef]

4. Aziret M, Çetinkünar S, Erdem H, Kahramanca Ş, Bozkurt H, Dülgeroğlu O, et al. Comparison of open appendectomy and laparoscopic appendectomy with laparoscopic intracorporeal knotting and glove endobag techniques: a prospective observational study. Turk J Surg 2017:33:258-66. [CrossRef]

5. Aziret M, Karaman K, Ercan M, Vargöl E, Toka B, Arslan Y. Early laparoscopic cholecystectomy is associated with less risk of complications after the removal of common bile duct stones by endoscopic retrograde cholangiopancreatography. Turk J Gastroenterol 2019;30:336-44. [CrossRef]

6. Corcione F, Pirozzi F, Aragiusto G, Galante F, Sciuto A. Laparoscopic splenectomy: experience of a single center in a series of 300 cases. Surg Endosc 2012;26:2870-6. [CrossRef]

7. Vasilescu C, Stanciulea O, Tudor S. Laparoscopic versus robotic subtotal splenectomy in hereditary spherocytosis. Potential advantages and limits of an expensive approach. Surg Endosc 2012;26:2802-9. [CrossRef]

8. Corcione F, Esposito C, Cuccurullo D, Settembre A, Miranda N, Amato $F$, et al. Advantages and limits of robot-assisted laparoscopic surgery: preliminary experience. Surg Endosc 2005;19:117-9. [CrossRef]

9. Schwartz SI. Splenectomy for hematologic disorders. In: Hyatt JR, Phillips EH, Morgenstern L (eds). Surgical Diseases of the Spleen. Springer, 1997:131-41. [CrossRef]

10. Remmele W. Funktionen der Milz. In: Remmele W (ed). Pathologie 1. Springer, 1984:496. [CrossRef]

11. Rezai P, Tochetto SM, Galizia MS, Yaghmai V. Splenic volume model constructed from standardized one-dimensional MDCT measurements. AJR Am J Roentgenol 2011;196:367-72. [CrossRef]

12. Misiakos EP, Bagias G, Liakakos T, Machairas A. Laparoscopic splenectomy: current concepts. World J Gastrointest Endosc 2017;9:428-37. [CrossRef]

13. Matharoo GS, Afthinos JN, Gibbs KE. Trends in splenectomy: where does laparoscopy stand? JSLS 2014;18:e2014.00239. [CrossRef]

14. Maurus CF, Schäfer M, Müller MK, Clavien PA, Weber M. Laparoscopic versus open splenectomy for nontraumatic diseases. World J Surg 2008;32:2444-9. [CrossRef]

15. Pattenden CJ, Mann CD, Metcalfe MS, Dyer M, Lloyd DM. Laparoscopic splenectomy: a personal series of 140 consecutive cases. Ann R Coll Surg Engl 2010;92:398-402. [CrossRef]
16. Brody FJ, Chekan EG, Pappas TN, Eubanks WS. Conversion factors for laparoscopic splenectomy for immune thrombocytopenic purpura. Surg Endosc 1999;13:789-91. [CrossRef]

17. Dan D, Harnanan D, Gooden K, Seetahal S, Hariharan S, Naraynsingh V. Laparoscopic splenectomy in a minimal resource setting: a case series from the Caribbean. Surg Laparosc Endosc Percutan Tech 2010;20:e125-8. [CrossRef]

18. Vecchio R, Milluzzo SM, Troina G, Cacciola E, Cacciola RR, Catalano $R S$, et al. Preoperative predictive factors of conversions in laparoscopic splenectomies. Surg Laparosc Endosc Percutan Tech 2018;28:e63-e67. [CrossRef]

19. Giza DE, Tudor S, Purnichescu-Purtan RR, Vasilescu C. Robotic splenectomy: what is the real benefit? World J Surg 2014;38(12):3067-73. [CrossRef]

20. Boddy AP, Mahon D, Rhodes M. Does open surgery continue to have a role in elective splenectomy? Surg Endosc 2006;20:1094-8. [CrossRef]

21. Patel AG, Parker JE, Wallwork B, Kau KB, Donaldson N, Rhodes MR, et al. Massive splenomegaly is associated with significant morbidity after laparoscopic splenectomy. Ann Surg 2003;238:235-40. [CrossRef]

22. Walsh RM, Brody F, Brown N. Laparoscopic splenectomy for lymphoproliferative disease. Surg Endosc 2004;18:272-5. [CrossRef]

23. Shin RD, Lis R, Levergood NR, Brooks DC, Shoji BT, Tavakkoli A. Laparoscopic versus open splenectomy for splenomegaly: the verdict is unclear. Surg Endosc 2019;33:1298-303. [CrossRef]

24. Owera A, Hamade AM, Bani Hani OI, Ammori BJ. Laparoscopic versus open splenectomy for massive splenomegaly: a comparative study. J Laparoendosc Adv Surg Tech A 2006;16:241-6. [CrossRef]

25. Silecchia G, Boru CE, Fantini A, Raparelli L, Greco F, Rizzello M, et al. Laparoscopic splenectomy in the management of benign and malignant hematologic diseases. JSLS 2006;10:199-205. [CrossRef]

26. Cavaliere D, Solaini L, Di Pietrantonio D, D'Acapito F, Tauceri F, Framarini $M$, et al. Robotic vs. laparoscopic splenectomy for splenomegaly: a retrospective comparative cohort study. Int I Surg 2018;55:1-4. [CrossRef]

27. Bodner J, Kafka-Ritsch R, Lucciarini P, Fish JH $3^{\text {rd }}$, Schmid T. A critical comparison of robotic versus conventional laparoscopic splenectomies. World J Surg 2005;29:982-5. [CrossRef]

28. Gelmini R, Franzoni C, Spaziani A, Patriti A, Casciola L, Saviano M. Laparoscopic splenectomy: conventional versus robotic approach-a comparative study. J Laparoendosc Adv Surg Tech 2011:393-8. [CrossRef] 


\section{ORIJINAL ÇALIŞMA-ÖZET}

Turk J Surg 2020; 36 (1): 72-81

\section{Intraoperatif splenik hilus kanaması ve splenomegali robotik ve laparoskopik splenektomiden açık cerrahiye geçişe etki eden risk faktörleridir}

Mehmet Aziret ${ }^{1}$, Bülent Koyun ${ }^{1}$, Kerem Karaman ${ }^{1}$, Cenk Sunu ${ }^{2}$, Alper Karacan ${ }^{3}$, Volkan Öter ${ }^{1}$, Fehmi Çelebi ${ }^{1}$, Metin Ercan ${ }^{1}$, Erdal Birol Bostancl ${ }^{1}$

${ }^{1}$ Sakarya Üniversitesi Eğitim ve Araştırma Hastanesi, Genel Cerrahi Kliniği, Sakarya, Türkiye

${ }^{2}$ Sakarya Üniversitesi Eğitim ve Araştırma Hastanesi, Hematoloji Kliniği, Sakarya, Türkiye

${ }^{3}$ Sakarya Üniversitesi Eğitim ve Araştırma Hastanesi, Radyoloji Kliniği, Sakarya, Türkiye

${ }^{4}$ Sağlık Bilimleri Üniversitesi Ankara Şehir Hastanesi, Genel Cerrahi Kliniği, Ankara, Türkiye

\section{ÖZET}

Giriş ve Amaç: Minimal invaziv cerrahi tüm dünyada farklı klinik pratiklerde etkili ve güvenli popüler tedavi yöntemlerinden biridir. Bu çalışmada amacımız, robotik veya laparoskopik splenektomi (RLS)'den açık cerrahiye geçişe etki eden risk faktörlerini ve indirekt hilum diseksiyonu tekniğinin performansını ortaya koymaktır.

Gereç ve Yöntem: Çalışmaya izole dalak hastalıkları nedeniyle RLS splenektomi yapılan 56 hasta kabul edildi. Hastalar iki gruba ayrıldı; RLS yapılan hastalar (grup 1) ( $n=48)$ ve açık cerrahiye geçilen hastalar (grup 2) ( $n=8)$. Hastalar yaş, cinsiyet, beden kütle indeksi (BKi), yandaş hastalık, tanı, ASA skoru, dalak çapı, biyokimyasal, mikrobiyolojik parametreler ve morbiditeler açısından retrospektif olarak değerlendirildi.

Bulgular: Yaş, cinsiyet, BKi, ASA skoru, yandaş hastalık, operasyon süresi, hastanede kalış süresi, takip süresi, aksesuar dalak, tanı, Uluslararası Normalizasyon Oranı (INR), eritrosit dağılım genişliği (RDW), trombosit dağılım genişliği (PDW), trombosit-lenfosit oranı (PLR), nötrofil-lenfosit oranı (NLR), tekrar başvuru, splenozis, cerrahi alan infeksiyonu, vasküler trombüs ve insizyonel herni açısından gruplar arasında istatistiksel olarak farklııı yoktu ( $p>0,05)$. Diğer taraftan, açık splenektomiye geçilen grupta intraoperatif splenik hilustan kanama ve dalak çapı istatistiksel olarak daha fazlaydı $(p<0,05)$. Multivaryant analizde açı̆̆a geçişe etki eden faktörler; intraoperatif hilustan kanama $(B=4,127)(O R=61,974)(\% 95 \mathrm{GA}=$ $3,913-981,454)(p=0,003)$ ve artmış dalak çapı $(>400 \mathrm{~cm} 3)(B=3,114)(O R=22,509)(\% 95 \mathrm{GA}=1,818-278,714)(p=0,015)$ olarak tespit edilmiştir

Sonuç: İntraoperatif splenik hilustan kanama ve artmış dalak çapı $\left(>400 \mathrm{~cm}^{3}\right)$ elektif RLS'den açık splenektomiye geçişe etki eden risk faktörleridir. İndirekt splenik hilum diseksiyonu intraoperatif kanama ve açık cerrahiye geçişi azaltabilir.

Anahtar Kelimeler: Açık cerrahiye konversiyon, indirekt hilum diseksiyonu, laparoskopik splenektomi, robotik splenektomi

Doi: $10.5578 /$ turkjsurg.4535 